\title{
JURGEN HABERMAS AND HIS CONTRIBUTION TO THE THEORY OF DELIBERATIVE DEMOCRACY
}

\author{
Dr. Aleksandar Jovanoski \\ Associate Professor of Sociology \\ Law Faculty - Kicevo \\ University of St. Clement of Ohrid - Bitola, Macedonia \\ E-mail: aleksandarjovanoski3@gmail.com, aleksandar.jovanoski@uklo.edu.mk \\ Dr. Kire Sharlamanov \\ Full Professor of Sociology \\ International Balkan University - Skopje, Macedonia \\ E-mail: sharlamanovk@gmail.com
}

\begin{abstract}
The paper presents Jürgen Habermas' epistemological views on the theory of deliberative democracy. Habermas has been constructing a series of assumptions since the 1970ies about his Theory of Communicative Action to overcome the crisis of legitimacy. This position stems from the critique of the deep chasm that exists between the "constitutional-democratic legal order" as a normative framework and how forms of social power are imposed to undermine the legitimate process of passing laws. The course of Habermas's argumentation theorizing about communicative action and the communicatively based process of (democratic) political decisionmaking brings with it the potential to break with the procedural argumentation of the representatives of the so-called aggregate models of democratic practice. For the development of the theory of deliberative democracy, its sociological sharpness may be important, with the help of which the social basis of legal projects and public policies leads to the clarification of the external tension that exists between facticity and validity. Thus, Habermas respects the differences between facts and norms in every contemporary concept of law. This can be called the legal theory of deliberative democracy that has shaped the modern understanding of the conception and practice of deliberative democracy.
\end{abstract}

Keywords: Deliberative Democracy, Jürgen Habermas, Communicative Action, Facts, Norms, Sociology, Political Science.

\section{Introduce the Problem}

\section{INTRODUCTION}

Although the term "deliberative democracy" is thought to have been first used by Joseph Bassett (1980) in the context of interpreting the US Constitution as a set of principles that ensure effective public "deliberation," especially in Congress - the development of this form of democracy, owes most to the two most prominent authors and founders in contemporary political philosophy and the theory of morality in politics: John Rawls and Jürgen Habermas. Briefly, before exposing Jürgen Habermas's view and influence on the development of the theory of deliberative 
democracy, brief prehistory of theorizing what is called the deliberative model of political decision-making in the United States will be presented. Namely, John Gastil and William Keith note that the reflections on the democratic novelty can be found in the books of Mansbridge (1983) Beyond Adversary Democracy; then Benjamin Barber's (1984) bestseller - Strong Democracy, Fishkin's (1988) popular Atlantic Mounty essay in August 1988 - The Case for a National Caucus, and similar texts from the 1980-ies (cited by Gastil \& Keith, 2005). The treatment of this new form of democracy can also be represented by contrast. De Griff points out - the theory of deliberative democracy understood as the essential opposite of the pluralistic or group-interest political representation reaches a further contrast, a contrast in which the previous legitimation of aggregate liberalism (in which the parties most often represent whole) is replaced by legitimacy due to "the rational acceptability of the law (or law) to all concerned, and where rational acceptability can be established only under conditions of free and open deliberation" (de Greiff, 2002: 377). Such definitions of deliberative democracy include the definition given by Joshua Cohen when he says that:

at the heart of the theory is the belief that the results (of political decision-making - AJ) are legitimate insofar as they receive express consent by participating in the authentic deliberation of all those subjects to whom the question relates`(Cohen, 1989: 17-34)

Similar to de Griff and Cohen, Ian Shapiro places the contemporary debate on the future of the theory of democracy and political representation in a framework that determines, on the one hand, the already suppressed literature on aggregate models of democracy and the literature on direct forms of political decision-making. - the latter is partly motivated by the impatience with the aggregate model. According to Shapiro, the theorists of the deliberative model of democracy seek to find a more robust and solid ground for common interest (or good) than the sum of already established voting preferences (Shapiro, 2003: 10).

\section{Method}

Given that this is theoretical research, the paper uses several characteristic methods such as discursive analysis, bibliographic analysis, content analysis, and similar semantic and analytical tools.

\section{REVIEW LITERATURE}

The first text to mention deliberative democracy is considered to be Joseph Basset's Deliberative Democracy published in the collection of Robert Goodwin and William Shambra How Democracy Was Constituted (Goldwin \& Shambra, 1980). The term was later used by Manin (1987) and Joshua Cohen in 1989. Dryzek (1990) has published a book entitled Discursive Democracy: Politics, Policy, and Political Science, which outlines the basic theoretical perspectives on deliberative democracy. This book has a special historical significance, especially considering that Dryzek is considered a follower of Habermas's tradition in discourse, and Habermas's most important book on deliberative democracy Between Facts and Norms (1996) was published six years later. Some authors go so far as to characterize Dryzek as a liberal state-centric conspirator of deliberative democracy, and as such distinguish him from the hard advocates of pure deliberative democracy - such as Habermas (see Chambers, 2003). Although many authors (e.g., Blau, 2007) criticize this parallelism in the use of discursive and deliberative democracy as synonyms - primarily due to epistemological differences - it is quite certain that the authors think of the same kind of democracy - the deliberative, hence this book. can be considered one of the 
pioneering works in the development of theory. The era of discursive development of the theory of deliberative democracy is usually considered to be in the 90 -ies of the last century.

\section{JÜRGEN HABERMAS STANDPOINTS: A THEORY OF COMMUNICATIVE ACTION}

The theoretical views of the theory of deliberative democracy, of one of the most important (later) representatives of the Frankfurt School, and according to many perhaps the most important philosopher of the second half of the last century, can be said that are built within a broader philosophical system. Habermas begins this system with an epistemological review of what he calls a theory of communicative action (early 1970ies) and ends with views of a shared and future political identity of a common Europe built towards the turn of the century. Throughout these few decades of Habermas's opus, it is possible to locate several constant and consistent positions that form the framework of his sociological or philosophical teaching on politics and the field of politics. Above all, it is the insistence on the moral dimension in all types of political action and all conditions, the transformation of individual political action into collective action, for which dialogue is necessary.

\section{In the mid-1970-ies, Habermas developed his theory of communicative action ${ }^{1}$.}

To this end, Habermas relies, among other things, on (but also criticizes) some of the views of Hannah Arendt - one of the last most important representatives (or followers) of critical theory. In his essay (1976) entitled Hannah Arendt's Communicative Concept of Power, Habermas accepts her break with Weber's views and the views of his followers within the Frankfurt School, who perceive power (primarily political power) in terms of rational purpose. an actor who is solely interested in the success of his action. With this position, Habermas breaks out of the trap into which Horkheimer and Adorno ${ }^{2}$ fall a few decades earlier. In that case, the one who acts in the field of politics acts primarily through the so-called "strategic" and less through "communicative" action. However, the turning point at which Habermas steps away from Arendt's views is to give space to strategic action in the realm of the political. In the context of such a created political practice, "legitimate power arises from those who form a form of shared belief in communication, which is protected from coercion." Such "shared beliefs" create legitimate power that strategic actors later complete. Competition between strategic actors can take the form of normalized, i.e., institutionalized power, but it can never become legitimized power (Habermas, 1976: $112,182,183)$.

In the very beginnings of the conception of the theory of communicative action, Habermas' dilemmas about the justification of certain views are present. What Habermas begins in the first part of the two-volume Theory of Communicative Action (1984) - the justification of the communicative way of rational action of each subject in the process of policy-making, reaching a common consensus and political decision-making - he concluded with Between Facts and Norms (1996), where his sociological aptitude for the social basis of legislative projects and public policies leads to the identification of the external tension that exists between the facticity and validity $^{3}$. Habermas here unequivocally stands out with the necessity of sociological respect for the differences between facts and norms in every contemporary concept of law and laws. Namely, the one-sidedness of a several political theories and approaches to the problem of power and governance stems from the inability to point to the deep abyss that exists between the "constitutional-democratic legal order" as a normative framework (probably alienated and inappropriate to reality) and "ways to which the forms of social power are imposed to undermine 
the legitimate procedure of passing laws" (Habermas, 1996: 9-17). However, the leap in Habermas's argumentation theorizing about communicative action and the communicatively based process of (democratic) political decision-making carries the danger of breaking the procedural argumentation and the evolutionary path of the foundations from which the theory of deliberative democracy later developed.

The communicative model of action does not equate action with communication. Language is a means of communication that serves for mutual understanding, where actors coming to mutual understanding also coordinate their actions, strive for certain goals ... Concepts of social action are determined by how they specify this coordination between target-oriented actions of diverse participants - as an intertwining of egocentric calculations of benefits, as a socially integrating consensus on norms and values instilled through cultural tradition and socialization, or as an understanding of the direction of a cooperative process of interpretation. The interpretive achievement on which the cooperation process is based is a mechanism for coordination of actions; communicative action is not exhausted by the act of reaching understanding (Habermas, 1984: 101$)^{4}$.

Joining Arnold Gehlen's views expressed in the theory of institutions, Habermas would later assess that the communicative contribution to contemporary law should be freed from the repeated guarantee of social cohesion. On the other hand, according to Habermas, social integration cannot be based only on rational foundations (individual interests) and the forces of solidarity - they need at least more money and power as two integration mechanisms, which to ensure longevity need to be legitimized (Habermas, 1996: 59). In the same vein of argumentation, Habermas abandons possessive individualism, most prominent of which is represented by Immanuel Kant's economic theory, and the absolutization of popular sovereignty (which often means the subjugation of individual rights in favor of the tyranny of the majority). the principle of law. According to this principle, the subjective rights of individuals do not refer in themselves to the alienated individual, but are based on the political autonomy of individuals - who use it in communication mediation according to which those norms of action apply to which all possibly affected individuals as stakeholders of rational discourse could agree" (Habermas, 1996: 138).

The assumption of the existence or achievement of common beliefs embodied through mutual communication is a significantly different conception of political decision-making or policy-making through mutual coercion. However, some authors seriously reprimand Habermas for being critical of the possibility of legitimizing power in completely safe conditions or conditions that are free from any potential for coercion ${ }^{5}$. This view is shared by Jane Mansbridge, among others, and is largely due to the precondition for making politically legitimate decisions through strategic action, which is completely free from any kind of coercion.

The whole political teaching of Habermas democracy begins with the need to identify the basic ethical postulates that underlie any communicative (dialogical) political action and determine the contour of the future consensus. Drawing inspiration and, among other things, upgrading the teachings of Peter Strawson, Habermas sees that "the justification of moral judgments and the responsibility that arises from them is part of the social practice that permeates life and interpersonal relationships." Based on the political debate or the process of political decisionmaking on the communicative action or persuasion of each other, Habermas assumes that the principle of universality as a subject of debate or deliberation must be understood as impartiality (Habermas, 1990: 68). Orientation to each other, in the whole political process, implies communicative action in which it is almost impossible for the individual to abstract or separately configure his goals from the socio-cultural environment in which he is socialized and with which 
he is connected. But if the political position of an individual separated from the environment or the community to which he is primordially assumed to belong is obtained, then, according to Habermas, such a form of (political) life undoubtedly has rudimentary determinants ${ }^{6}$.

For Habermas, there are a several postulates of political action that he cannot agree with. Among them, of course, is the claim that the condition of neutrality is satisfied when the individual, formulating moral judgments, fictitiously places himself in the position of every other interlocutor. He then considers that the task of moral argumentation is impossible to achieve in a way that does not provide for dialogue or cooperative efforts, just as the idea of neutrality cannot be reduced to the balance of power. In this way he distinguishes the qualitative difference that separates negotiation from participation in deliberation:

Participants in public speech tend to clarify the common interest, while in negotiation the compromise is the one that will impose a balance between opposing individual interests (Habermas, 1990: 72) ${ }^{7}$.

\section{BETWEEN FACTS ABD NORMS: THE BOOK THAT SHAPED THE THEORY OF DELIBERATIVE DEMOCRACY}

At the beginning of the development of Habermas's conception of deliberative democracy, there is something he calls a discursive theor $y^{8}$ of the democratic process. According to this Habermas view, discursive or deliberative democracy differs significantly from the liberal on the one hand and the republican (communist) interpretation on the other, of democratic politics. For Habermas, the liberal view of politics embeds the whole process of political decision-making in the "marketoriented network of relations between private actors" (Habermas, 1996: 21). The key embodiment of the whole machinery for the political functioning of the society and the coordination of the various individual interests has the government embodied through the apparatus of the public administration. The position or status of citizens in politics according to the liberal point of view, for Habermas is determined by the title of the negative rights of the individual, as opposed to any other individual and the state. Furthermore, the process of forming the general will within the liberal view is determined by a competition between the strategic actions of the collectives to achieve a position of power. In this case, there is a clear distinction between society on the one hand and the state on the other. In the end, the conflicting interests of the collectives are forced by compromise to reach the optimal decision for the interests of the largest possible number of individuals, which in most cases arises after a long bargaining procedure and under the label of justice (Habermas, 1996: 29).

On the other hand, the communitarian/republican explanation of the process of democratic political decision-making, perceived and presented by Habermas, practices politics in a way that means much more than a mediation function between different interests. In this case as well as in the liberal view of politics, the procedural form of the whole process is permeated along all lines and aspects, which emphasizes the form of the content. In the Republican representation of politics, there is a commitment to a differentiated set of common values that have been established for a long time and which, among other things, make individuals - political actors aware of the existence of others as equal and equal to them. According to this view, the immediacy of relations and the orientation of each other concerning to each other creates solidarity that serves as an adhesive for strengthening the political society but at the same time reaching a consensus in a communicative way. In contrast to the liberal view, political participation in the Republican view of politics is based on political rights that are positive freedoms. In the embodiment of political thought and general will, the key element is not the market (as with liberals) but the process of public 
communication which is aimed at achieving mutual understanding as to the basis of consensus (Habermas, 1996: 23).

Announcing the theoretical novum on the scene, Habermas makes a synthesis of the elements of both views of politics, at the moment when he tries to reduce the value of the procedural dimension of the formation of the general will (as a value legitimized by the previous "convergence of established ethics" convictions") and which, among other things, is based on communicative assumptions that provide better arguments that enhance the quality of deliberation (communitarian value) and second, on procedures that enable a fair bargaining process (Habermas, 1996: 24).

Given that liberalism legitimizes the democratic process through the compromise that is procedurally reached between the confronting parties, assuming fairness on the elements of representative democracy (general and equal voting rights, the composition of the legislature, decision-making rules, etc.), and republicanism relies on the culturally based background of shared consensus, discursive theory, or the theory of deliberative democracy, in its beginnings, Habermas postulates it as a synthesis of the above elements:

... and integrates these into the concept of an ideal deliberation and decision-making procedure. Interweaving pragmatic considerations, compromises, discourses of self-understanding and justice, this democratic procedure is based on obtaining a reasonable and just result. According to this procedural point of view, practical reason derives from universal human rights, or a specific ethical substance of a given community, into rules of discourse and forms of argumentation. In the final analysis, the normative content derives from the structure of the communicative action (Habermas, 1996: 26).

\section{MORALITY AND POLITICS IN HABERMAS S THEORY OF DELIBERATIVE DEMOCRACY}

Emphasizing the inevitability of a communicatively based political decision-making process in which the public determines the direction of the political, Habermas tries and succeeds in strengthening the private autonomy of the individual in the form of negative freedoms. In that way, the imperative of being held accountable for one's public action and taking responsibility is ignited in the individual. This, according to Reese-Schafer, is the key moment of Habermas's theorizing, which is why it was decided at the beginning of the sketching of a discursive theory of democracy to be neutral in terms of both morality and law (Reese-Schafer, 2004: 10). With this Habermas begins the tradition within the discourse of deliberative democracy to identify questions that can be asked as the subject of deliberation. Avoiding the practice of enumerating areas that can be deliberated (which we will see later is not the case with his most famous followers) Habermas tries to determine at the level of principles the problems that may need to come up in public at the public hearing.

- First, the interesting-calculating questions about how to match competing preferences: the question of aggregate overall will.

- Second, the ethical and political issues of whom we want to become. This question is the subject of hermetic discourses of self-understanding and is directed to the authentic whole will, and

- Third, the moral-practical question of how we want to act in a just way relates to autonomous overall will (Habermas, 1996).

By identifying the areas or properties of the problem for which it can be deliberated, Habermas already gives the direction in which at least one of the currents in the discourse will develop. It 
thus gave far greater theoretical and epistemic weight to the theory of deliberative democracy. At least for the views of his followers.

Accused of a proceduralist view of deliberative democracy, Habermas seeks to introduce, or rather validate, the normative component of contemporary democratic theory into an intermundium that has a stronger norm than liberal views and yet weaker than communist republicans. Building his theory closer to communist views, Habermas places deliberative democracy in a deeply decentralized society in which there is an extensive "institutionalization of correspondence procedures and conditions of communication." Deliberative democracy also implies a high degree of intersubjectivity in the communication process that flows from representative bodies (parliament for example) to informal networks in/on the public sector. And hence:

\begin{abstract}
Deliberation is supposed to inevitably provide a medium for more or less conscious integration of the legal community, but this model does not extend to the whole society in which the political system is embedded only between a few subsystems. Even according to its procedural selfunderstanding, deliberative politics remains part of a complex society, which as a whole resist the normative approach practiced in legal theory (Habermas, 1996: 30)9.
\end{abstract}

Many believe that, in fact, Habermas, in an attempt to provide a basis for his theory of deliberative democracy, is giving the normative notion to the public. The public in this case would have a less enlightening mission than to form a synthesized form of coexistence of the creations of opinion and administrative decision-making. Building the institutions as the locus operandi of this project, Habermas in the early 1960ies postulated the deliberative democracy as a simultaneous and normative measure of the present and a real-utopian project of the future ${ }^{10}$.

Developing his discursive theory of democracy within the framework of critical theories of law, Habermas actually avoids the trap, or rather the weakness, of many of his contemporary theorists - to place civil partnership at the center of their theorizing, and often as a point of reference. their views. Instead, Habermas seeks and succeeds in imposing a comprehensive "citizenship science of law in which he integrates the rules of the rule of law, the logic of separation of powers, the rationality of jurisdiction and even civil law"11. As Habermas himself points out in Between Norms and Facts, the relationship between law and politics in the new discursive theory of democracy (deliberative democracy) implies

democratic rule of law as an institutionalization of procedures and communication assumptions for the discursive formation of opinions and will, which take place with the help of legitimate law (which in addition guarantees private autonomy) and which on the other hand allows ... the legitimate establishment of law (Habermas, 1996: 527).

Following the influence of Habermas's thinking on the theory of deliberative democracy, it is possible to observe continuity throughout his creative life. That continuity starts from his theory of morality, through the discursive theory of democracy to the procedural conception of popular sovereignty ${ }^{12}$.

\title{
CONCLUSION
}

Undoubtedly, the great contribution of Jürgen Habermas in the construction of the epistemological postulates of the theory of deliberative democracy - that is, of one of the two most important schools in the discourse. Habermas' commitment to the project of finding an alternative model of political decision-making is evident from the very beginning of the conception of the theory of 
communicative action. What Habermas begins in the first part of the two-volume Theory of Communicative Action (1984) - the justification of the communicative way of rational action of each subject in the process of policy-making, reaching a common consensus and political decisionmaking - he concluded with Between Facts and Norms (1996), where its sociological aptitude for the social basis of legislative projects and public policies leads to the identification of the external tension that exists between facticity and validity. Habermas here unequivocally stands out with the necessity of sociological respect for the differences between facts and norms in every contemporary concept of law and laws.

Another area in which Habermas made an invaluable contribution to the theory of deliberative democracy is his distinction between the types of public spheres. Distinguishing between the so-called hard and soft environments in the public for political decision-making, Habermas emphasized the advantage of the propulsive public where although unlike the solid and binding nature of the hard environments for political decision-making there is no capacity to affect the conclusions of deliberation, there is still room for more extensive treatment of public interest. As Habermas explained, soft environments in the public act as a kind of "research context" in which they allow the masses to act as the so-called a resonator or research group, and as such relieved of the burden of legally binding decisions is more sensitive to problems that do not reach the agenda of the formal political system

Evaluating the process of rationalization as something that carries more weight than the mere constitution of power but less than legitimacy, Habermas frees the decision-making process in deliberative democracies from exposing the "populist moods of active citizens." According to his argument, in the end, the identification card is only an additional confirmation of the essential process. That is, as Habermas himself points out in, Between Norms and Facts, the communicative structures of the public create what might be called "broadly branched networks of sensors" but they cannot rule, although they respond to existing problems in society. "Since it has been established that communicative power cannot exercise power alone, it can still have a significant impact on determining the direction of future policy." This is especially feasible given Habermas' remark that if power is tied to institutions to fulfill its function, then power also exists in relationships that are not precisely or formally rounded off. After all, this is one of the strongest arguments of Habermas, which develops the idea of discursive or deliberative democracy, and in which argument one of the key positions has civil society.

\section{REFERENCES}

Barber, B. (1984) Strong Democracy: Participatory Politics for a New Age. Berkley, Los Angeles and London: University of California Press.

Blau, J. (2007). Human Rights, Environmental Justice, and Popular Democracy, Rowman \& Littlefield.

Cohen, J. (1989). Deliberation and Democratic Legitimacy. In Hamlin, A. and Pettit, P. (eds.) The Good Polity: Normative Analysis of the State, (pp. 17-34), Oxford: Basil Blackwell.

Chambers, S. (2003). Deliberative Democratic Theory. Annual Review of Political Science 6, 307- 26. 
de Greiff, P. (2002). Deliberative Democracy and Punishment. BUFFALO CRIMINAL REVIEW $5.373-404$

Dryzek, J. S. (1990). Discursive Democracy: Politics, Policy, and Political Science, Cambridge: Cambridge University Press.

Dryzek, J. S (2000). Deliberative Democracy and Beyond: Liberals, Critics, Contestations, Oxford: Oxford University Press.

Fishkin, J. S. (1988). The Case for a National Caucus: Taking Democracy Seriously. Atlantic Monthly (August), 18.

Gastil, J., \& Keith, W. (2005). A Nation that (Sometimes) Likes to Talk: A Brief History of Public Deliberation in the United States. In Gastil, J. \& Levine, P. (Eds.) The Deliberative Democracy Handbook (pp. 3-19), San Francisco: John Wiley and Sons.

Goldwin, R. A., \& Shambra, W.A. (1980). How Democratic is the Constitution? Washington, DC: American Enterprise Institute

Gutman, A., \& Thompson, D. (1996). Democracy and Disagreement. Cambridge Massachusetts: Harvard University Press,

Habermas, J. (1976). Hannah Arendt's Concept Communications of Power. In Social Research, $44(1)$.

Habermas, J. (1984). The Theory of Communicative Action Vol. I: Reason and the Rationalization of Society. Boston: Beacon Press.

Habermas, J.( 1990). Moral Consciousness and Communicative Action. Cambridge: Massachusetts MIT Press.

Habermas, J. (1996). Between Facts and Norms: Contributions to a Discourse Theory of Law and Democracy. Cambridge: Polity Press

Horster, D. (1992). Jürgen Habermas' Rechtspbilosophie, Die Neue Gesellshaft/Franfurter Heffte, (39), Cited in Reese-Schafer, W. 2004 Jürgen Habermas ideliberativna demokracija. Zagreb: Politička misao, 41(4), 3-21.

Luhman, N. (1993). Das Recht der Gesellschaft. Frankfurt am Main, 64.

Manin, B. (1987). On Legitimacy and Political Deliberation. Political Theory, 15(3), 338-68.

Mansbridge, J. (1983). Beyond Adversary Democracy. Chicago and London: The University of Chicago Press. 
Nino, K. S. (1996). The Constitution of Deliberative Democracy. New Haven \& London: Yale University Press.

Rawls, J. (1993). Political Liberalism. New York: Columbia University Press.

Reese-Schafer, W. (2004). Jürgen Habermas i deliberativna demokracija. Zagreb: Političkamisao, 41(4), 3-21.

Shapiro, I. (2003). The State of Democratic Theory, Princeton and Oxford: Princeton University Press.

\section{NOTES}

Note $^{1}$ This assessment is based on the published scientific papers in which Habermas begins to develop the theory of communicative action, but according to his intimate confession in the preface to the first volume of The Theory of Communicative Action (1984), he begins by conceptualizing this teaching. as early as the early 1970-ies. Namely, in that period his attitude towards Durkheim's communicative-theoretical reformulation of the theory of social action, Parsons' theory of the social system, and Mead's theory of social interaction matured. The positions of these three sociologists serve as the foundation from which he builds the colossal theory of communicative action, in the light of "the need to overcome post-Cartesians and methodological solipsism as a scientific approach, and with the help of communicative action to explain the growth of capitalist society." which he has witnessed from a critical distance. When it comes to intimate confession and giving credit to his predecessors and collaborators who influenced his work, the influence exerted by Weber's explanation of the sources of Occidental rationalism is inevitable. It is also worth noting the great gratitude that Habermas sends to Thomas McCarthy, his collaborator, and friend, who at a critical time helped Habermas to continue his work (Habermas, 1984: xxxix), and later as a serious scholar of Habermas's works. and theoretical views become the most famous translator of his works into English.

Note $^{2}$ In the absence of a solid factor that justifies the purposeful action of political actors, they invoked or reactivated Weber's notion of instrumental reason.

Note $^{3}$ The reference to 1996 as the date when one of the most influential studies of influential German was published should be considered with caution as it refers to the English translation and edition used here. Originally, under the title Faktizität und Geltung, this book was published by Habermas in 1992 and marks a significant contribution to contemporary debates on the future of several scientific disciplines such as sociology of law, theory of law, history of law and, the like, but what some followers of this debate consider Habermas's greatest contribution to be the step from the previous framework of legal theorizing. For a paradigm of this skewed view, they take the book of Luhmann (1993) Das Recht der Gesellschaft. Some authors point out that by extensively presenting the theoretical foundations of communicative action and discursive democracy, Habermas made a significant difference in the crystalline analysis. For this, Gutman and Thomson consider the differentiation of the sociology of law from the philosophy of justice, which in turn places Habermas among the successors of Kant's theory of cognitive ethics, linking him to a group of theorists such as Paul Lorengen, Ernst Tugendant Karl Otto Appeal, but also Rawls (1993) himself. However, Habermas's ability to distinguish the nuances of a meta discursive debate in which the sociological theory of law and the philosophical theory of justice are differentiated is only able to begin a long series of theorizing in which he seeks to mediate "Political theory of deliberative democracy and civil partnership because to ensure sufficient openness is not the rigid constitutionally established state institutions, but the sovereignty of public deliberation." According to Rees-Schaefer, Habermas's virtuosity in avoiding the weaknesses of both disciplinary approaches, "the danger of normative theory of justice not knowing sufficiently rigid political facts and the suspicion that positivism has too much influence on sociological theory results in interdisciplinary theory (probably the author is thinking here of something very close to social theory - underlined AJ) with which he tries to overcome the double simplification. (Gutman \& Thompson, 1996; Reese-Schafer, 2004: 8).

Note $^{4}$ Although in this part the comparison with the views of John Rawls as the most important representativeopponent (opponent) of the competing conception of deliberative democracy may seem inappropriate, still pointing out some differences in their argumentation may clarify some of the disciplinary weaknesses in the process or lending theses about deliberative democracy. From the quote, it can be seen that Habermas does not even remotely share 
Rawls' belief in the contractual formation and reaching of the ruling consensus, nor does the configuration of individual interests - according to the British utilitarian tradition - take them into a process of self-definition and expression. and a pre-determined political bargaining agenda. On the contrary, they largely depend on the rooting in cultural traditions, and the process of reaching a political consensus depends on the interpretive potentials within the social interaction. Although understanding or consensus, according to the theory of communicative action, is relatively easy to achieve, it does not close the scope and duration of the communicative action itself. Given Rawls' initial views on the attainment of social justice within a "well-organized society" by accepting two universally accepted principles, these extensive ontological aspirations of Habermas, despite his disrespect for communist literature (such an assessment stems from in the bibliography of his two volumes of The Theory of Communicative Action no work of any communist is pointed out) create a solid basis for marking the initial positions of the two dominant currents in the discourse of deliberative democracy as a communist-liberal conflict.

Note $^{5}$ Although here it is worth noting some critical observations of such starting positions of Habermas. Apart from the fact that this view is very reminiscent of Rawls' two principles of social justice, the principle expressed in this view is obviously that he prefers ethics to law. As such, a moral principle does not imply a binding weight as implied or expected by positive legal regulations. That is why, among other things, many institutionally oriented connoisseurs of Habermas's thought object that despite the weak normative connotation, the neutrality towards morality and law that marks the quoted position, does not allow maintaining the border that divides these two areas. After all, the tension that Habermas intensifies in one way or another only complements the existing and contradictory principle of division between the factual and the justifiable, which persists throughout the argumentation Between Facts and Norms. Hence, Habermas also distinguishes between the moral principle - which, in his view, operates at the level of the "internal structure of a particular argumentation game" and the democratic principle - which refers to the level of external institutionalization (Reese-Schafer, 2004: 10).

Note $^{6}$ To this degree of understanding of Habermas's position, certain pro-communitarian views are noted, which are shared in some degree also by John Rawls in his Theory of Justice. This is primarily about the need to reach a consensus on shared moral foundations and neutrality as a principle of political debate. However, after these initial positions, some of the insurmountable differences between these two leaders of the theory of deliberative democracy are overseen. First, where for Rolls there are formal assumptions of monologue moral reasoning, for Habermas, there are rules of the social practice of intersubjective debate. Second, Rawls believes that the demand for impartiality is sufficient to justify the moral principle of political debate, while Habermas seeks de facto agreement to be reached through the rule of impartiality. Third, while Rawls considers the moral principle to be valid when achieved through the very means of individual reflection, while discussion can only be an aid, Habermas is adamant that only collective discussion is a confidential way to access moral knowledge (Nino, 1996: 112).

Note $^{7}$ These claims are placed by certain authors and critics of Habermas's philosophy inappropriate categories of general principles which they call epistemological or ontological constructivism. According to epistemological constructivism, moral judgment is not established as a consequence of the concrete speech, but through its assumptions which, if known, are a reliable way to achieve the desired result. Ontological constructivism, on the other hand, is based on the view that the justification of a moral court - not just knowledge of that court - is created as a result of real discussion, if it satisfies or exceeds the given limitations.

Note $^{8}$ In the literature, especially among the followers of the Habermas tradition in the development of the theory of deliberative democracy, the practice of synonymous use of certain deliberative and discursive is noticeable. However, the use of these two terms as alternatives creates some ambiguity among contemporary authors and critics of this theory. Following in the footsteps of Nancy Fraser's theorizing within her perspectives - and especially the emphasis on "subaltern audiences", John Dryzek, as Habermas's most important follower and connoisseur, appreciates that discourse theory, however, should be debated democracy. According to Dryzek, the existence of alternative public actors (Fraser - subterranean counter-republic) with an agenda to be aimed at the holders of solid power. In the setting itself, there is a qualitative difference in the content of the process - competition versus deliberation (Dryzek, 2000: 27).

Note ${ }^{9}$ Habermas's briefly sketched discursive theory of democracy or deliberative democracy is a continuation of the Frankfurt sociological school tradition, which in this author's work is most recognizable in both volumes of the theory of communicative action. the sociological approach to the deliberative model of democracy, where the political system is neither at the top nor at the center of society but is just another subsystem, more specifically a system of action within the wider social system. Such assessments must not lead to a way in which the theory of deliberative democracy would be placed exclusively among the theories of the system from modern sociological theories.

Note $^{\mathbf{1 0}}$ This assessment is expressed by Reese-Schafer from the position of a critic with a certain dose of sociological ingenuity (Resse-Schafer, 2004: 12).

Note $^{11}$ This assessment is underlined by Horster, 1992: 11-39. 
Note $^{\mathbf{1 2}}$ The latter is the subject of his later writings in which he attempts to offer a comprehensive theory of European identity and shared or shared citizenship. This part of Habermas's teaching is not the subject of this analysis.

\section{Copyrights}

Copyright for this article is retained by the author(s), with first publication rights granted to the journal. This is an open-access article distributed under the terms and conditions of the Creative Commons Attribution license (http://creativecommons.org/licenses/by/4.0) 